\title{
LOCAL RESIDENTS' PARTICIPATION IN TOURISM AT A WORLD HERITAGE SITE AND LIMITATIONS: A CASE OF AKSU-JABAGLY NATURAL WORLD HERITAGE SITE, KAZAKHSTAN
}

\author{
Imanaly AKBAR \\ State Key Laboratory of Desert and Oasis Ecology, Xinjiang Institute of Ecology and \\ Geography, Chinese Academy of Sciences, Urumqi 830011, China University of \\ Chinese Academy of Sciences, Beijing 100049, China, e-mail: yimanaili_akebaier@yahoo.com
}

\section{Zhaoping YANG*}

State Key Laboratory of Desert and Oasis Ecology, Xinjiang Institute of Ecology and Geography, Chinese Academy of Sciences, Urumqi 830011, China, e-mail: yangzp@ms.xjb.ac.cn

\section{Ordenbek MAZBAYEV}

L.N. Gumilyov Eurasian National University, St. Satbayeva 2, Almaty district, Nur-Sultan 01000o, Kazakhstan, e-mail: ordenbek@mail.ru

\section{Aday SEKEN}

L.N. Gumilyov Eurasian National University, St. Satbayeva 2, Almaty district, Nur-Sultan 01000o, Kazakhstan, e-mail: adai_seken@mail.ru

\section{Madeleine UDAHOGORA}

State Key Laboratory of Desert and Oasis Ecology, Xinjiang Institute of Ecology and Geography, Chinese Academy of Sciences, Urumqi 830011, China University of Chinese Academy of Sciences, Beijing 100049, China, e-mail: udahogoram@gmail.com

\begin{abstract}
Citation: Akbar, I., Yang, Z., Mazbayev, O., Seken, A. \& Udahogora, M. (2020). LOCAL RESIDENTS' PARTICIPATION IN TOURISM AT A WORLD HERITAGE SITE AND LIMITATIONS: AKSU-JABAGLY STATE NATURE RESERVE, WESTERN TIAN-SHAN, KAZAKHSTAN. GeoJournal of Tourism and Geosites, 28(1), 35-51. https://doi.org/10.30892/gtg.28103-450
\end{abstract}

\begin{abstract}
One of the core elements of tourism development is considered to encourage local communities' participation in World Heritage (WH) tourism because of its vital role in the sustainability. Albeit more and more scholars have attached much importance on researching developing tourism fields of the country, unfortunately, very few researches have been undertaken to identify and analyze major issues in natural world heritage tourism in Kazakhstan, including the management structure, financial resources, tourism impacts, policy making and local community participation. In this context, there is a need to explore what level such communities can participate in the tourism at World Heritage sites (WHS) where tensions between preservation and tourism are notable. The main purpose of this article is to indicate the local residents' participation in heritage tourism and analyze
\end{abstract}

\footnotetext{
* Corresponding author
} 
the impacting factors on their participation. In our research, we conducted a questionnaire survey of 222 representative households from two neighboring settlements of Aksu-Jabagly natural world heritage site. The results of the research show that the inhabitants do not actively participate in the development of tourism. The results also reveal that few travelers' coming to this tourist destination and lack of preferential policies were the primary restrictions for local residents' participation in tourism.

Key words: Residents' participation, tourism development, world heritage, AksuJabagly nature reserve, Kazakhstan, limitation, sustainable tourism

\section{INTRODUCTION}

Tourism is considered to be one of the most active and important industry in many countries and plays a vital role by contributing to economy of many developing countries. In addition, the tourism industry has provided many opportunities for governments to live in the global economic space, thus it has been stimulating the development of urban and rural economy (UNWTO, 2013). Tourism has become a major strategy for communities to achieve economic, social and ecological benefits, which can promote community development and poverty reduction (Binns \& Nel, 2002). With the fast development of tourism, the role of the community in tourism development has increased, and in order to balance the status of communities and other related stakeholders in the development of tourism, it is important to increase the participation of community residents in tourism development (Inskeep, 1991). Most experts agree with the idea that local residents' involvement in tourism planning in the heritage area adjacent to their neighborhood has many benefits, such as get achieving sustainability and increasing local economy. The participation of local people in the conservation of World Heritage Site (WHS) and the tourism planning there will help improve the quality of life of local residents and make the heritage protection plan more sustainable (Friedman et al., 2009, Sirisrisak, 2009). In addition, community participation in tourism of local WHS increases residents' feeling of belonging, promotes the development of social networks, and attaches great importance to the value of local district ( $\mathrm{McCool} \&$ Martin, 1994; Gursoy et al., 2002; Tosun, 2002). According to Mann (2000), community involvement can make distributing benefits and costs more efficient and more equitable, and more importantly, help people's self-development and knowledge sharing. Local communities play a significant role in reviving and sustaining WHSs, and thus, participation of local community in tourism activities at the WHS is essential for the sustainable tourism development (Rasoolimanesh \& Jaafar, 2016). Community participation in WHS management can address conflicts and assist in clarifying the concept of heritage among community members (Sirisrisak, 2009; Su \& Wall, 2014).

Several studies have attested the role of public participation in sustaining heritage conservation programs (Nicholas et al., 2009; Yung \& Chan, 2013). Local residents' participation in tourism activities at the heritage sites contributes to their economic development, and improves their overall quality of life (Sirisrisak, 2009). Community participation in tourism development at the WHSs is significant and necessary for improving people's welfare and conserving heritage area effectively. Therefore, involvement of local community in heritage tourism has been valued as a key development opportunity for local residents there. Although their abundant local knowledge and experience of the heritage conservation are admitted generally, local 
residents, who are affected by heritage tourism mostly, are always neglected (Tosun, 2000) and as the 'owner' and custodian of heritage, local communities rarely have full control over the site and planning of tourism development (Scheyvens, 2003). At the WHSs, preservation and development work is implemented by local people and international authorities. Thus, involvement of local communities in heritage tourism is essential (Timothy \& Tosun, 2003) to reduce negative impacts and ensure fair distribution of tourism benefits. At the same time, there are a number of obstacles of local residents' participation in tourism in least developed and some developing countries. Scheyvens (2003) claimed that albeit its importance, community involvement is constrained by a number of factors, such as residents' lack of knowledge, confidence, time, and interest.

Sometimes, some stakeholder groups may even become hostile, sabotaging, or politically manipulative. The importance of community participation in natural resource management and the tourism development have long been debated in western academic and planning circles (Agrawal, 2000; Archabald \& Naughton-Treves, 2001; Brohman, 1996; Inskeep, 1991; Prentice, 1993; Ryan \& Montgomery, 1994; Simmons, 1994; Stræde \& Helles, 2000). However, due to economic, socio-cultural and political conditions there are a number of differences between western societies and countries in Asia. Some limits described by Tosun (2000) in terms of barriers to community participation in developing countries can be found in Kazakhstan, especially in the centralization of public administration. On the one hand, 'Residents and other stakeholders' participation in decision-making has not been recognized as important in planning documents, nor has it been addressed in practice' (Timothy, 1999). On the other hand, most of the residents are reluctant to participate in regional tourism decision-making and management.

Simply say, for various reasons discussed by $\mathrm{Gu}$ and Ryan (2009), the application of principles of stakeholder participation to tourism planning in developing countries are difficult, although an objective of such planning is commonly the development of benefits for local communities. Additionally, except for issues of administrative structures, other issues also exist in the tourism development in the developing countries like Kazakhstan. The urgent one is the relatively early stages of tourism development. This means there is a lack of experience on the part of operating in the tourism industry. For residents, this lack of knowledge can be further handicapped if there are varying degrees of education level that indicates not all residents have the possibility to access the necessary requirements of full involvement in planning process. Today Kazakhstan tourism planning is heavily oriented towards the development of cultural tourism, and nature based tourism just around developed big cities, such as Nur-Sultan and Almaty. Developing community based tourism in marginalized rural areas are not perceived as important, at where having advantages of developing many types of tourism in one time, for example, ecotourism, equestrian tourism, ethnic tourism, agritourism and rural tourism. And the local residents are the most valuable human resources for tourism development. This study attempts to analyze this phenomenon given the local importance of residents in that region.

\section{village}

Study area overview: Aksu-Jabagly State Nature Reserve and Jabagly

Western Tien-Shan is a transnational site, one of the largest mountain ranges in the world. It spans over three countries: Kazakhstan, Kyrgyzstan and Uzbekistan. On 17 July 2016, during the World Heritage Committee's 40th session in Istanbul, Turkey, it was inscribed on UNESCO's World Heritage List to protect its biodiversity. Western TienShan covers 467,550 hectare $\left(4675.5 \mathrm{~km}^{2}\right)$ at an altitude ranging from 700 to $4,503 \mathrm{~m}$. It spans over three Important Bird and Biodiversity Areas (IBBAs): The Aksu-Jabagly State Nature Reserve, the Kenshektau Mountains and the Bashkyzylsay Unit of the Chatkal 
Mountains Biosphere Reserve. This is Kazakhstan's second natural site to be declared a World Heritage Site, while it is Kyrgyzstan's and Uzbekistan's first. The Western TienShan trans-boundary serial nomination, lying within the Republics of Kazakhstan, Kyrgyzstan and Uzbekistan, consists of 13 component parts covering a combined area of 528,178 ha plus 102,916 ha of buffer zones (whc.unesco.org 2016).

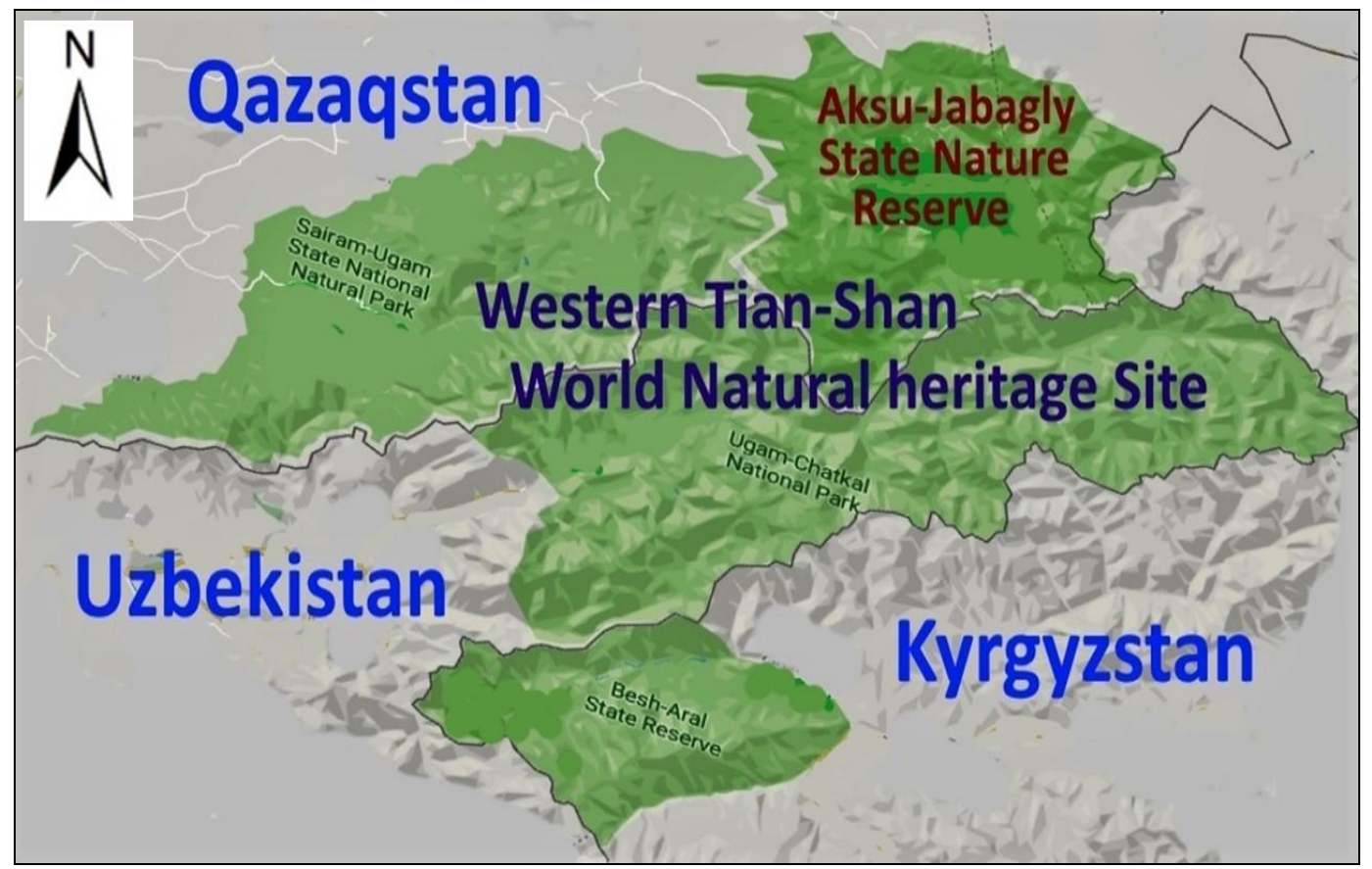

Figure 1. Sketch of main parts of Western Tien-Shan natural world heritage site

The Aksu-Jabagly State Nature Rreserve, established in 1926. It is located in the western extremity of Talasski Alatau ridge and ranges at elevations from $1100 \mathrm{~m}$ to $4238 \mathrm{~m}$ (Sayram Peak). There are two main rivers in this nature reserve called Aksu and Jabagly respectively. Aksu river length is $120 \mathrm{~km}$ and the Jabagly River is twice shorter. The rivers take their sources from heavy ice and snow at mountain peak. There are 114 ice hills in the reserve. There are many lakes in the territory of the reserve, all of which are situated at a very high altitude. The reserve is also abundant with mineral waters. As one of the main protected zones of Western Tian-Shan natural world heritage site, Aksu-Jabagly nature reserve features diverse landscapes, which are home to exceptionally rich biodiversity. It is of global importance, as an origin place, for a number of cultivated fruit crops and is home to a great diversity of forest types and unique plant community associations. AksuJabagly nature reserve is home for more than 1,279 recorded species of flora, 57 of them registered in the Red Book of republic Kazakhstan including the Greig's Tulip (the symbol of the reserve). There are 267 species of birds in the territory, 52 mammals, 11 reptiles, and 3 species of amphibians. There are also some endangered birds and animals in the nature reserve, such as Egyptian vulture, eagles, black stork, brown bear, Arkhar, paradise flycatcher, snow leopard, Central Asian lynx etc. There are 2124 species of insects, more than 63 species of mussels, 64 species of algae, 235 mushrooms and 1312 species of plants. The bush contains 62 types (KazakhstanNationalCommittee, 2014). 
Aksu-Jabagly State Nature Reserve consists of 3 zones, lies in Tulkibas district of Turkistan region, Jualy district of Jambyl region of the Republic of Kazakhstan. Main part of nature reserve (N42 16 34, E70 40 27) has 131,704 ha property zone and 25,800 ha buffer zone. Other two zones are Karabastau paleontological area (N42 56 24, E69 54 54) and Aulie paleontological area (N42 54 18, E70 oo oo) with only property zones, 100 ha and 130 ha respectively (whc.unesco.org 2016).

Jabagly village - administrative unit of Tulkibas district. It includes the Jabagly, Abaiyl and Russian Railway 115 settlement. The total population of the Jabagly village is 3048 people, including 2401 people of Jabagly settlement, 545 people of Abaiyl settlement and 102 people of settlement Russian Railway 115. The center of the village is Jabagly settlement. And Jabagly settlement is $17 \mathrm{~km}$ southeast to the Turar Ryskulov town (former Vannovka), administrative center of Tulkibas district. Jabagly settlement has a public transport connection with Turar Ryskulov town and Shymkent city (passport of Jabagly village, 2019). Lying adjacent to the West Tien Shan Mountains, Jabagly settlement is the gateway to Aksu-Jabagly State Natural Reserve. The main economic activities are agriculture, plant growing and cattle breeding. $59 \mathrm{~km}$ area of Tulkibas is located along Western Europe-Western China (WE-WC) Highway, and it leads convenience to travel to Jabagly village by car for visitors.

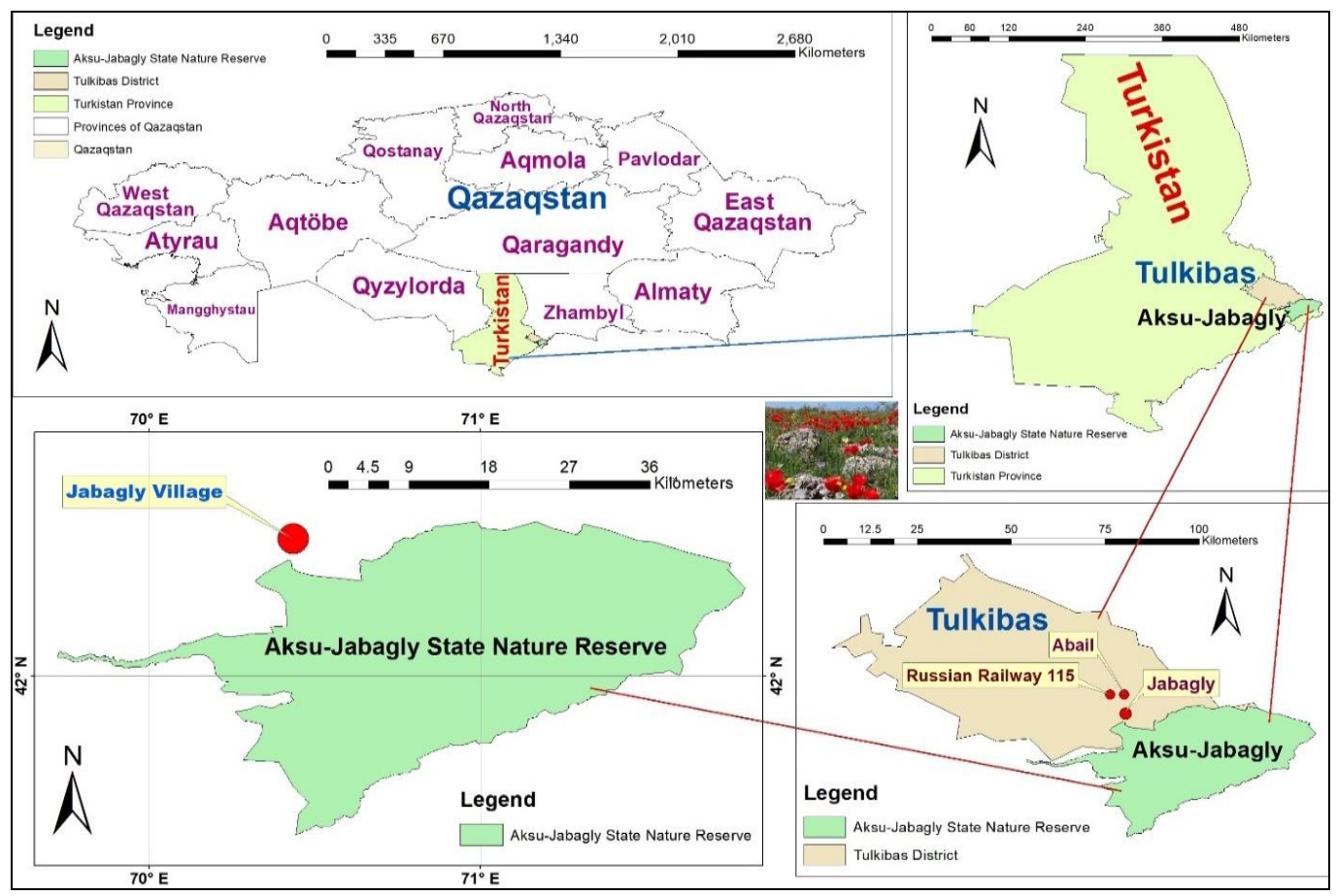

Figure 2. Selected research area, Aksu-Jabagly state nature reserve and Jabagly village

\section{Aksu-Jabagly natural world heritage tourism}

The implementation of the world heritage structure, especially in rural areas, has achieved global impact because they become a venue characterized by a global vision and traditional rural elements. However, construction always increases local and regional development possibilities since conservation measures tend to stimulate tourism (Butler 
et al., 1998). WH designation specifies challenges involving stakeholders at all levels of society, but the combination of natural and landscape conservation and the simultaneous increased potentials in tourism development may be particularly prone to occur conflicting views and interests (Svels, 2015). In a globalized, multidimensional world, WH stakeholders are numerous and heterogeneous. However, the most significant daily relationship in WHSs is still between local residents and tourists. The common apparent impact of WH tourism, together with its effects as perceived by locals, is both vital for a balanced and sustainable development. Tourism relies mostly on the benefits of the local residents and therefore their support and participation are significant for its sustainability. However, reshaping local heritage into a fully viable tourism environment, local communities may also begin to influence and ultimately jeopardize the $\mathrm{WH}$ values (Nicholas et al., 2009). Therefore, developing tourism at a world heritage site, it is necessary to consider its characteristics, for example developing tourism in ecologically sensitive protected areas the best strategy is to organize tourism activities at the buffer zone of the protected areas. In this respect, our research area, Aksu-Jabagly biodiversity conservation site can be one of the best examples. Because there in accordance with the "Specially Protected Natural Territories" law of the Republic of Kazakhstan, areas, which are not included valuable ecological systems, are allowed to organize ecological excursions under the control of authorities, as well as, some trails and regular tourist routes are created by the licensed tourism sectors (KazakhstanNationalCommittee 2014).

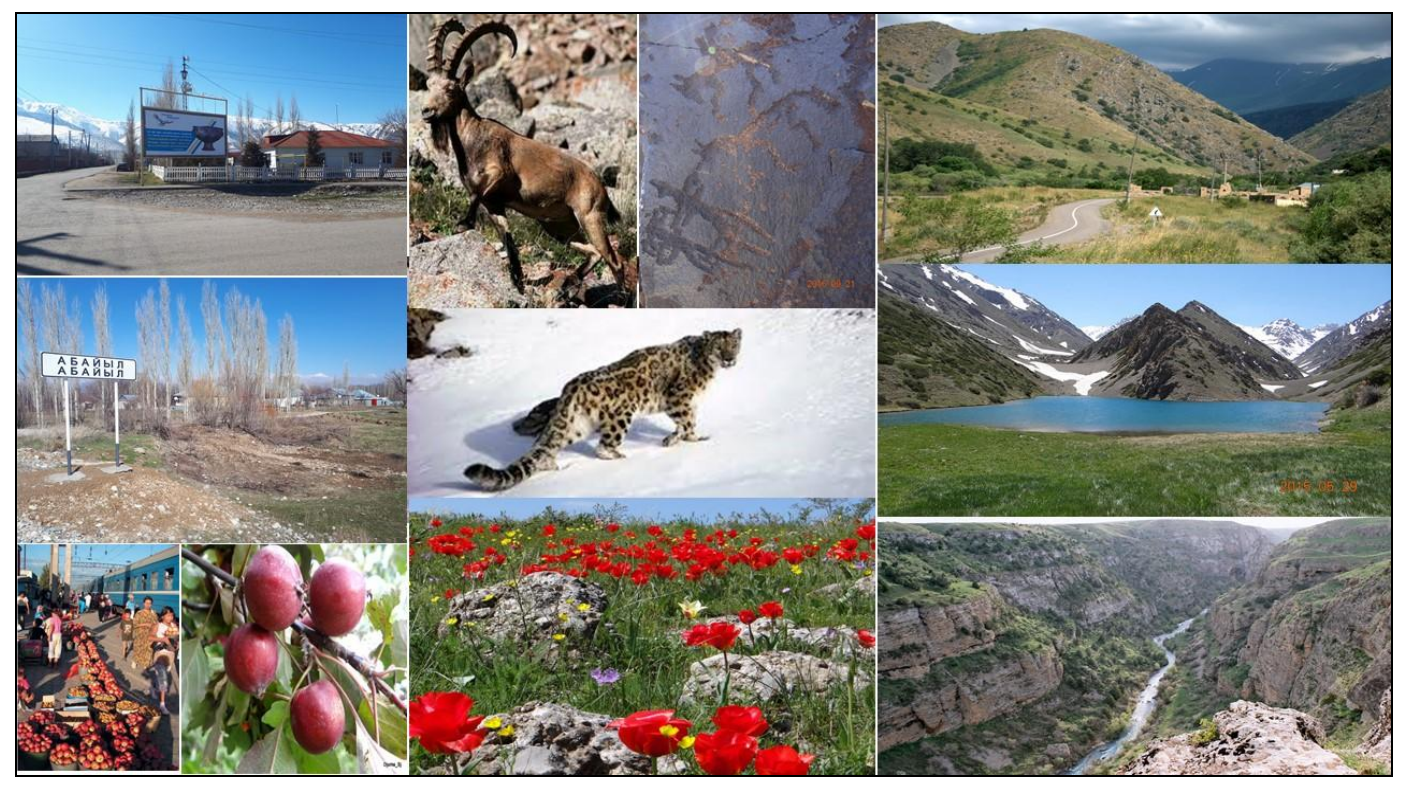

Figure 3. Two selected settlements of Jabagly village and Aksu-Jabagly world heritage site (Source: aksu-jabagly.kz and Imanaly AKBAR)

On the territory of Aksu-Jabagly state nature reserve, there are currently three ecological paths and seven excursion routes, which are equipped with information boards, signposts, shelters aimed to study and observe the flora, fauna and landscape. Ecological paths created in natural areas conservation for development of ecotourism and environmental education for population and tourists are intended for general acquaintance with the nature of protected areas and for educational purposes. 
Before starting a route, each group or individual tourist is instructed, the rules of conduct on the route are issued and required to sign in a safety diary. Guides lead a tour of the trail and watch out the group. If necessary, unplanned stops are made. Designed trails and routes are classified: 1) by appointment: scientific, educational and touristexcursion; 2) by type of movement: pedestrian, horse and car. Tourists are divided into groups, hiking group must be no more than 10 people and equestrian group must be no more than 6 people, every group should be accompanied by tour guide. And there is strict quota for the numbers of tourists to visit the nature reserve every day.

The head of environmental education and tourism department of Aksu-Jabagly state nature reserve, Zhumanova Elmira Perdebaevna said that the nature reserve receive four groups every day (Mynzhasarhyzy, 2018). It means very few number of tourists are allowed to enter daily the core zones of the nature reserve. When we observed our research area, we found that although national and local authorities have paid very close attention to protect the core zones, they failed to develop tourism in the buffer zone of the protected area, instead permitting other industries, such as animal husbandry and farming, which lead threats to the ecological protection.

\section{MATERIALS AND METHODS}

A mixed methods research design was employed, integrating quantitative and qualitative methods in data collection and analysis. Questionnaire surveys and key informant interviews were used as the major primary data collection methods. Government documents and tourism statistics facilitated the effective execution of the surveys and interviews and complemented results for primary data analysis.

Representatives both from Jabagly settlement and Abaiyl settlement residents were interviewed, at the same time, in order to understand local residents' participation level comprehensively. Director of the scientific research department of Aksu-Jabagly state nature reserve office, the mayor of the Jabagly village and the director of the travel company "Zhana-Talap" in Shymkent city were also interviewed with some specific questions concerning the influential factors of local residents' passive participation in tourism activities. Face-to-face interviews with aforementioned experts and all questionnaire surveys were conducted in three weeks. Interview and survey questions include local residents' supports for and participation in tourism development at the Aksu-Jabagly natural world heritage site, and the main reasons why local residents do not participate in tourism development.

The questionnaire to all relevant respondents was designed with three major sections. Section 1 was designed by ticking " $\checkmark$ " on the corresponding option to acquire basic information about their gender, age, ethnic and education level. Section 2 was designed with some multiple choice questions indicating annual household income, current engaging industry, number of people who engage in tourism in their family, tourism income rate in their annual household income and the most suitable industry for buffer zone of Aksu-Jabagly Nature Reserve to understand local residents' economic situation and participation level in tourism generally, and obtain respondents' opinions on industries which have more advantages to develop at the buffer zone of the heritage site in the future. Section 3 evaluates respondents' perceptions of statements regarding local residents' supports for and participation in tourism development at the AksuJabagly natural world heritage site and the main reasons why local residents do not participate in tourism development. Question items in the section 3 encouraged respondents to answer on a 5-point Likert scale questions with 1 (fully agree), 2 (agree), 3 (neutral), 4 (disagree) and 5 (fully disagree). Data collection occurred over a 20 -day 
period from $2^{\text {nd }}$ of March to $22^{\text {th }}$ of March, 2019, with respondents selected from Jabagly settlement (166 people out of 1571 economically active population) and Abaiyl settlement ( 56 people out of 275 economically active population).

We went to the aforementioned two settlements and issued our questionnaire to respondents personally. Using five point Likert-scale options, the respondents were asked for their opinion on total 14 questions, including 7 statements regarding the local residents' supports for and participation in tourism development at the Aksu-Jabagly natural world heritage site and left 7 statements are about the main reasons why local residents do not participate in tourism development by indicating 1 (fully agree), 2 (agree), 3 (neutral), 4 (disagree) and 5 (fully disagree).

\section{RESULTS DISCUSSIONS}

Table 1 shows that of the 222 respondents, 166 were from Jabagly and 56 were Abaiyl settlements. According to Kazakh national traditions, specially, in small rural areas men usually take care of earning for living and women take care of housework and children, so we interviewed approximately two times more men than women with $66.3 \%$ and $67.9 \%$ from Jabagly and Abaiyl settlements, respectively. The respondents were categorized into three age groups: young age group (ages between 18-34) with 60 respondents from Jabagly and 22 respondents from Abaily, middle age group (35-54) with 88 respondents from Jabagly and 27 respondents from Abaily, and elder group $(\geq 55)$ with 18 respondents from Jabagly and 7 respondents from Abaily. Most of the respondents were Kazakh ethnicity with 152 and 52 people from Jabagly and Abaiyl settlements, respectively. At the same time, questionnaires were answered by 8 Russian ethnic people and 6 other ethnic groups in Jabagly settlement and 2 Russian and 2 other ethnic groups in Abaiyl settlement. Most of the respondents had secondary to middle (school or college) education level with 142 respondents from Jabagly and 50 from Abaiyl while only a few respondents had a high (university or above) education level with 24 respondents from Jabagly and 6 respondents from Abaiyl.

\section{Jabagly Village Local Residents' Participation in WH Tourism Development}

Kazakhstan, with its rich cultural and natural heritage resources, joined the World Heritage Convention after 2000. The Minister of Foreign Affairs of Kazakhstan, Mr. Kaiarat Abdrakhmanov, affirmed the importance of UNESCO for peace, security and sustainable development during a meeting with Director-General Irina Bokova on 29 March 2017 (UNESCO 2017). The positive impact of tourism on community can encourage local residents to support the development of tourism, and its negative impacts have ceased their favor for tourism development (Sharpley, 2014). In addition, the positive impacts of tourism development on community contributes to local residents' participation in sustainable tourism activities (Nicholas et al., 2009).

And the diversity of residents' perception by tourism development influences the level of residents' support for and participation in tourism development (Easterling, 2005). Tosun (2000) analyzed the pattern of community participation in tourism and its characteristics with reference to tourism development and argued that higher-levels community participation were more conducive to the evolution of sustainable tourism development. He contended that passive participation meant an elementary-level involvement in tourism development and its object was as much to prevent a too hurried residents' intervention into tourism development by providing residents with longer term sustainable participation opportunities. Thus, with Jabagly village and the adjacent AksuJabagly state nature reserve as a study area, this research examines local residents' 
support and participation in tourism development at the Aksu-Jabagly natural world heritage site and the main reasons why they do not participate in tourism activities in their hometown through assessing the perceptions of local residents from two settlements of Jabagly village lying next to the natural world heritage site.

Table 1. Profile of respondents

\begin{tabular}{|c|c|c|c|c|}
\hline \multirow{2}{*}{ Characteristics } & \multicolumn{2}{|c|}{ Jabagly $(n=166)$} & \multicolumn{2}{|c|}{ Abaiyl $(n=56)$} \\
\hline & Frequency & Percentage & Frequency & Percentage \\
\hline \multicolumn{5}{|l|}{ SECTION 1} \\
\hline Gender: & & & & \\
\hline Male & 110 & 66.3 & 38 & 67.9 \\
\hline Female & 56 & 33.7 & 18 & 32.1 \\
\hline Age (years): & & & & \\
\hline Young $(18-34)$ & 60 & 36.2 & 22 & $39 \cdot 3$ \\
\hline Middle age (35-54) & 88 & 53 & 27 & 48.2 \\
\hline Elder $(\geq 55)$ & 18 & 10.8 & 7 & 12.5 \\
\hline \multicolumn{5}{|l|}{ Ethnicity: } \\
\hline Kazakh & 152 & 91.6 & 52 & 92.8 \\
\hline Russian & 8 & 4.8 & 2 & 3.6 \\
\hline Other & 6 & 3.6 & 2 & 3.6 \\
\hline \multicolumn{5}{|l|}{ Education: } \\
\hline Middle (school or college) & 142 & $85 \cdot 5$ & 50 & 89.3 \\
\hline High (university or above) & 24 & 14.5 & 6 & 10.7 \\
\hline & & & & \\
\hline \multicolumn{5}{|l|}{$\begin{array}{l}\text { Annual household income: } \\
\text { (KZ Tenge, } 1 \$=375 \text { tenge) }\end{array}$} \\
\hline Below 500,000 & 11 & 6.6 & 6 & 10.7 \\
\hline $500,000-1$ million & 82 & 49.4 & 30 & 53.6 \\
\hline 1 million -1.5 million & 60 & 36.2 & 17 & 30.4 \\
\hline 1.5 million - and above & 13 & 7.8 & 3 & $5 \cdot 3$ \\
\hline \multicolumn{5}{|l|}{ Current engaging industry: } \\
\hline Tourism & 17 & 10.2 & 2 & 3.6 \\
\hline Animal husbandry & 81 & 48.8 & 11 & 19.6 \\
\hline Farming & 39 & 23.6 & 7 & 12.5 \\
\hline Business & 18 & 10.8 & 6 & 10.7 \\
\hline Other industry & 11 & 6.6 & 30 & 53.6 \\
\hline \multicolumn{5}{|l|}{$\begin{array}{l}\text { Number of people who engage } \\
\text { in tourism in your family: }\end{array}$} \\
\hline & 149 & 89.8 & 54 & 96.4 \\
\hline 1-2 people & 13 & 7.8 & 2 & 3.6 \\
\hline 3 and above & 4 & 2.4 & 0 & $\mathrm{O}$ \\
\hline \multicolumn{5}{|l|}{$\begin{array}{l}\text { Tourism income rate in your } \\
\text { nnual household income: }\end{array}$} \\
\hline $\begin{array}{c}\text { nnual household income: } \\
\text { o \% }\end{array}$ & 149 & 89.8 & 54 & 96.4 \\
\hline $1-20 \%$ & 12 & 7.2 & 2 & 3.6 \\
\hline $21-60 \%$ & 4 & 2.4 & o & o \\
\hline $61-100 \%$ & 1 & 0.6 & $\mathrm{O}$ & o \\
\hline \multirow{2}{*}{\multicolumn{5}{|c|}{$\begin{array}{l}\text { Suitable industry for the buffer zone } \\
\text { of Aksu-Jabagly Nature Reserve: }\end{array}$}} \\
\hline & 87 & 52.4 & 38 & 67.9 \\
\hline Animal husbandry & 45 & 27.1 & 8 & 14.3 \\
\hline Farming & 27 & 16.3 & 6 & 10.7 \\
\hline Forestry & 7 & 4.2 & 4 & 7.1 \\
\hline
\end{tabular}


Section 2 of table 1 showed Jabagly settlement had a slightly better economic background than Abaiyl settlement according to their annual household income comparison. Because population of annual household income of "below 500,000" and "500,000 -1 million" in Jabagly settlement with $6.6 \%$ and $49.4 \%$ were less than Abaiyl settlement's $10.7 \%$ and $53.6 \%$. And population of annual household income of "1 million -1.5 million" and "1.5 million - and above" in Jabagly settlement with $36.2 \%$ and $7.8 \%$ were more than Abaiyl settlement's 30.4.7\% and 5.3\%. As far as their current engaging industries are concerned, there are more residents in Jabagly settlement (10.2\%) engaged in tourism than in Abaiyl settlements (2\%). And most of the population of Jabagly settlement engaged in animal husbandry and farming, with $48.8 \%$ and $23.6 \%$ respectively while more than half of the total population in Abaiyl settlement engaged in other industry with $53.6 \%$. In this study Section 2 of table 1 also showed that $89.8 \%$ of Jabagly people and $96.4 \%$ of Abaiyl residents' jobs had nothing to do with tourism industry. 1-2 people's participation in tourism was $7.8 \%$ in Jabagly settlement and $3.6 \%$ in Abaiyl settlement while 3 and above people' participation in tourism was $2.4 \%$ in Jabagly and $\mathrm{o} \%$ in Abaiyl. Comparing the tourism income rate in household income, families from Jabagly, with tourism income rate of $1-20 \%, 21-60 \%$ and $61-100 \%$, were $7.2 \%, 2.4 \%$ and $0.6 \%$ respectively, however, there is only families with tourism income rate of $1-20 \%$ in Abaiyl, accounting for 3.6\%. From above statistical analysis we can easily conclude that both settlements had a weak involvement in tourism at the heritage site, however, residents from Jabagly settlement had slightly a greater number of people participating and tourism income rate than Abaiyl settlement. Here we preliminary say that the participation level of local residents in Jabagly settlement is higher than Abaiyl settlement. And the reasons which caused hese differences will be analyzed in the next section. In terms of multiple choice question of the most suitable industry for the buffer zone of Aksu-Jabagly Nature Reserve, both settlements' residents thought tourism industry was more appropriate than others, with $52.4 \%$ and $67.9 \%$ support respectively. Although they have a very low participation rate in the tourism business at the area of nature reserve, most residents support for developing tourism industry rather than animal husbandry, farming and forestry in the buffer zone of world heritage site.

The two settlements neighboring WHSs have apparently similar historical background. however, there are differences in the participation of communities in tourism activities on the heritage site, and the industries they have engaged are also various. How do local people evaluate the status of local residents' participation in tourism development at the WHS? The respondents' answers are expressions of their perceptions and therefore subject to interpretation. Given the result from the empirical data, the dissimilarity of opinions between statements regarding local residents' supports for and participation in tourism development at the Aksu-Jabagly natural world heritage site and the main reasons why local residents do not participate in tourism development is distinguishable, but not so clearly. Table 2 showed a five-point Likert-scale choice of selected questionnaire statement groups (SA and SB).

First, as far as statements of group A are concerned, majority of respondents from both Jabagly and Abaiyl settlements (SA1: mean $=1.67$ and mean $=1.96$ respectively and SA2: mean=1.69 and mean=1.91 respectively) supported the idea of conservation of nature reserve ecology through developing tourism at the heritage site and improving residents' wellbeing through developing tourism in the buffer zone of the nature reserve. One of the most essential elements of realizing sustainable tourism development at susceptible and vulnerable natures like Aksu-Jabagly natural world heritage site is the highly participation of local residents in the ecological protection of the heritage site. 
Local Residents' Participation in Tourism at a World Heritage Site and Limitations: A case of Aksu-Jabagly Natural World Heritage Site, Kazakhstan

Table 2. Statements from Jabagly and Abaiyl settlements'

participation in tourism and limitations survey

\begin{tabular}{|c|c|c|c|c|c|c|c|c|c|c|c|c|}
\hline Statements & \multicolumn{7}{|c|}{ Jabagly settlement $(\mathrm{n}=166)$} & \multicolumn{5}{|c|}{ Abaiyl settlement $(\mathrm{n}=56)$} \\
\hline $\begin{array}{l}\text { A. Local residents' supports } \\
\text { and participation in tourism } \\
\text { development at the Aksu- } \\
\text { Jabagly world heritage site }\end{array}$ & $\begin{array}{c}\text { Fully } \\
\text { agree } \\
(\%) \\
\end{array}$ & $\begin{array}{c}\text { Agree } \\
(\%)\end{array}$ & $\begin{array}{c}\text { Neutra } \\
(\%)\end{array}$ & $\begin{array}{c}\text { Disagree } \\
(\%)\end{array}$ & $\begin{array}{l}\text { Fully } \\
\text { disagree } \\
(\%)\end{array}$ & Mean & $\begin{array}{l}\text { Fully } \\
\text { agree } \\
\text { (\%) }\end{array}$ & $\begin{array}{c}\text { Agree } \\
(\%)\end{array}$ & $\begin{array}{c}\text { Neutral } \\
(\%)\end{array}$ & $\begin{array}{c}\text { Disagree } \\
(\%)\end{array}$ & $\begin{array}{c}\text { Fully } \\
\text { disagree } \\
(\%)\end{array}$ & Mean \\
\hline $\begin{array}{l}\text { 1. I support the strategy of } \\
\text { conservation of nature reserve } \\
\text { ecology through developing } \\
\text { tourism at the heritage site }\end{array}$ & 57.8 & 24.2 & 12.0 & 4.8 & 1.2 & 1.67 & 53.6 & 25.0 & 3.6 & 7.1 & 10.7 & 1.96 \\
\hline $\begin{array}{c}\text { 2. I support the strategy } \\
\text { of improving residents' } \\
\text { wellbeing through developing } \\
\text { tourism in the buffer zone } \\
\text { of the nature reserve }\end{array}$ & 54.2 & 27.7 & 13.9 & 3.0 & 1.2 & 1.69 & $55 \cdot 3$ & 21.4 & 5.4 & 12.5 & 5.4 & 1.91 \\
\hline $\begin{array}{c}\text { 3. I participate in } \\
\text { ecological protection } \\
\text { works of the nature reserve }\end{array}$ & 18.1 & 28.3 & 8.4 & 28.3 & 16.9 & 2.98 & 1.8 & 5.4 & 8.9 & 26.5 & $55 \cdot 4$ & $4 \cdot 30$ \\
\hline $\begin{array}{l}\text { 4. I participate in receiving } \\
\text { tourists in this tourism } \\
\text { destination }\end{array}$ & 14.6 & 23.1 & 20.2 & 24.3 & 15.8 & $|3.04|$ & 1.8 & 12.5 & 14.3 & 17.8 & 51.8 & 4.02 \\
\hline $\begin{array}{l}\text { 5. I participate in tourism } \\
\text { research works in this } \\
\text { tourism destination }\end{array}$ & 7.2 & 15.1 & 7.8 & 28.3 & 41.6 & 3.82 & 3.6 & 10.7 & 7.1 & 39.3 & 41.1 & 4.07 \\
\hline $\begin{array}{l}\text { 6. I participate in planning } \\
\text { of tourism activities in } \\
\text { this tourism destination }\end{array}$ & 6.6 & 16.9 & 7.8 & 24.7 & 44.0 & $\mid 3.83$ & 3.6 & 7.1 & 5.4 & 21.4 & 62.5 & 4.32 \\
\hline $\begin{array}{c}\text { 7. I participate in organizing } \\
\text { and managing tourism } \\
\text { activities in this tourism } \\
\text { destination }\end{array}$ & 12.0 & 18.1 & 6.0 & 23.5 & 40.4 & 3.62 & 3.6 & 10.7 & 7.1 & 39.3 & 41.1 & 4.07 \\
\hline $\begin{array}{l}\text { B.Themainreasonswhy local } \\
\text { residents do not participate } \\
\text { in tourism industry: }\end{array}$ & $\begin{array}{l}\text { Fully } \\
\text { agree }\end{array}$ & Agree & Neutra & Disagree & $\begin{array}{l}\text { Fully } \\
\text { disagree }\end{array}$ & Mean & $\begin{array}{l}\text { Fully } \\
\text { agree }\end{array}$ & Agree & Neutral & Disagree & $\begin{array}{c}\text { Fully } \\
\text { disagree }\end{array}$ & Mean \\
\hline 1. Shortage of necessary funds & 30.2 & 42.2 & 12.0 & 8.4 & 7.2 & 2.20 & 39.3 & 35.6 & 3.6 & 16.1 & 5.4 & 2.13 \\
\hline 2. Insufficient labor force & 24.1 & 39.2 & 6.0 & 22.3 & 8.4 & 2.52 & 28.6 & 30.4 & 8.9 & 14.3 & 17.8 & 2.63 \\
\hline $\begin{array}{l}\text { 3. The residential area is } \\
\text { located far from the } \\
\text { tourist destination }\end{array}$ & 3.0 & 4.8 & 4.2 & 9.6 & 78.4 & 4.55 & 82.1 & 5.4 & 1.8 & 7.1 & 3.6 & 1.45 \\
\hline $\begin{array}{l}\text { 4. There are very few visitors } \\
\text { to the tourist this destination. }\end{array}$ & 54.2 & 30.2 & 9.6 & 4.2 & 1.8 & $\mid 1.69$ & 60.7 & 19.6 & 5.4 & 8.9 & 5.4 & 1.79 \\
\hline $\begin{array}{l}\text { 5. Lack of knowledge } \\
\text { about tourism planning } \\
\text { and management }\end{array}$ & 24.1 & 36.1 & 21.1 & 12.7 & 6.0 & 2.40 & 8.9 & 32.1 & 53.6 & 3.6 & 1.8 & $\mathbf{2 . 5 7}$ \\
\hline $\begin{array}{l}\text { 6. Tourism business in this } \\
\text { tourism destination are } \\
\text { monopolized by a small } \\
\text { number of individuals or } \\
\text { organizations. }\end{array}$ & 9.6 & 18.1 & 42.2 & 19.3 & 10.8 & $|3.04|$ & 10.7 & 21.4 & 12.5 & 28.6 & 26.8 & 3.39 \\
\hline $\begin{array}{l}\text { 7. Lack of preferential policies } \\
\text { of supporting for local } \\
\text { residents to participate in } \\
\text { tourism development }\end{array}$ & 36.2 & 48.2 & 3.0 & 8.4 & 4.2 & 1.96 & $55 \cdot 3$ & 21.4 & $5 \cdot 4$ & 12.5 & $5 \cdot 4$ & 1.91 \\
\hline
\end{tabular}


And the statements regarding ecological protection works of the nature reserve was answered somewhat positively by Jabagly residents $\left(\mathrm{SA}_{3}\right.$ : mean $\left.=2.98\right)$ while it was responded more negatively by residents from Abaiyl (SA3: mean=4.30). And these result showed that all two settlements had a stronger support for the strategies of conservation and local development through tourism development at the heritage site, and residents from Jabagly settlement involved in heritage site conservation to some degree whereas very few people from Abaiyl took part in conservation work. Interviews support these findings. In terms of participation in receiving tourists, tourism research works, planning of tourism activities and organizing and managing tourism activities in this tourism destination, (SA4, SA5, SA6 and SA7), nearly all respondents answered negatively with mean above 3. And there was less participation level in Abaiyl settlement with mean above 4 comparing with Jabagly settlement (mean was between 3 and 4).

Among 4 statements assessing participation in tourism level, receiving tourists was answered by comparatively higher number of respondents with (SA4: mean=3.04 and mean $=4.02$ respectively) and planning of tourism activities was responded by lower number of residents from both settlements with (SA6: mean=3.83 and mean $=4.32$ respectively). This result shows that although this tourism destination had been inscribed in the list of world heritage site and tourism has been developed there, the local residents who are the most affected stakeholders of the heritage site have not participated in tourism activities well, and the overall participation level of Jabagly settlement was a little higher than that in Abaiyl settlement. And the influential factors of participation in tourism development at this tourism destination and participation dissimilarity between two settlements will be discussed in the following paragraph.

Second, answering questionnaires concerning the obstacles of residents' participation in tourism (SB), except for statement of far residential location from the tourist destination (SB3), nearly all impediments for local residents' participation in heritage tourism were replied with the approximately same answers. And shortage of necessary funds ( $\mathrm{SB} 1)$, labor force ( $\mathrm{SB} 2$ ) and knowledge about tourism planning and management ( $\mathrm{SB}_{5}$ ) were thought to be little handicap for both settlement residents' participations in tourism, with (SB1: mean $=2.20, \mathrm{SB}_{2}$ mean=2.52 and $\mathrm{SB} 5$ : mean $=2.40$ for Jabagly and SB1: mean=2.13, SB2 mean=2.63 and SB5: mean=2.57 for Abaiyl).

Far residential location (SB3) was the biggest impediment for Abaiyl settlement's local residents (mean $=4.55$ ) while it was considered as not an obstacle for residents from Jabagly (mean $=1.45$ ). And the most crucial two barriers for two settlements' participation in tourism were visitation of very few travelers to the tourist this destination, with (SB4: mean=1.69 and mean=1.79 for two settlements individually), and lack of preferential policies of supporting for local residents to participate in tourism, with (SB7: mean=1.96 and mean=1.91 for two settlements individually). There was a slightly negative perception by both settlements' residents on monopolization of tourism business in this area by a small number of individuals or organizations, with (SB6: mean=3.04 and mean=3.39 for two settlements individually). It means they have an equal opportunity for engaging in tourism industry to some extent. In conclusion, majority of respondents from two selected research area supported for tourism development strategies at Aksu-Jabagly heritage site. And the participation level of tourism activities at the heritage site was a little higher in Jabagly than in Abail settlement, nevertheless, overall participation status was very low. Considering all indicators regarding obstacles of local residents' participation in tourism development, respondents' perceptions were diverse between some statements. And the results of survey showed that a small number of tourists and lack of preferential policies of supporting for local residents' participation in tourism were 
the common reasons for all residents in two settlements, and farther residential location from the tourism destination was the primary reason for Abaiyl settlement's people.

When we interviewed three relative experts, the mayor of the Jabagly village, the scientific research department director of Aksu-Jabagly state nature reserve office and the director of the Zhana-Talao travel company, who knows local residents' participation situation in tourism at the Aksu-Jabagly state nature reserve, we found that although the world heritage tourism destination has a high popularity with nature based tourism through CIS (Commonwealth of Independent States) countries, few local residents engaged in tourism business. The Akim (mayor of village) claimed that the main two reasons were lack of business skills and laziness of the local residents. He also said most of the villagers have earned their living by relying on animal husbandry and farming, and "I will be very glad if they engage in tourism activities" (Mynzhasarhyzy, 2018).

The scientific research department director told us that the tourism activities in the core zone of the heritage site have been strictly controlled and monetarized by the heritage management office in Jabagly settlement, however, tourism planning and organizing events in the buffer zone have been controlled by very few skilled people, some of whom are not local residents. After highlighting the importance of protecting Aksu-Jabagly state nature reserve, he also asserted that although this village has great potential of developing other types of tourism on the basis of ecotourism at Aksu-Jabagly heritage site, such as rural tourism, agritourism and ethnic tourism, unfortunately, the government have not paid attention to this fact and the villagers have not been aware of the significance of developing community based tourism. interviewing the director of the Zhana-Talap travel company, we found that although many tourists have a big desire for visiting this tourism destination, there are existing some drawbacks that have banned coming of large number tourists to this tourism destination, for example low quality service facilities (including old car, tired horse and unprofessional local tour guides) and the higher accommodation price (Mynzhasarhyzy, 2018).

$\mathrm{Li}$ and Hunter (Li \& Hunter 2015) listed several reasons why full community involvement is difficult to achieve in heritage tourism practices: (1) The host community is never a naturally unified single entity, but comprises multiple stakeholder groups, which may hold diverse views and conflicting interests toward how it operates. (2) Not all stakeholder groups will participate as soon as such opportunity has been made available. (3) Based on different resources held, each stakeholder group may have varying degrees of influence over decision making in tourism companies - for example, the government agency that authorizes tourism operation licenses has a higher level of power than grassroots environmental protection NGOs (nongovernmental organizations).

Community involvement in decision-making is of particular importance and viewed as a prerequisite for fair distribution of benefits from tourism, especially in Western countries, however, in developing countries, it is rarely possible because of many restrictions (Li, 2006). A top-down, passive and indirect community participation approach is generally taken in tourism development in developing countries, as a result, others make decisions for the communities, and they only participate when implementing and sharing the benefits rather than making decisions about tourism planning (Tosun, 1999; Tosun, 2006). In a study of Jiuzhaigou Biosphere Reserve, China, Li (2006) discovered that Local communities benefit from tourism to much extent without involving in the planning process. Even though their significance and benefit, community participation studies have been evaluated in terms of theory and has been lacking in conceptual framework in terms of rural tourism (Tosun, 2006; Flaherty et al., 2006). Most of the scholars have proposed that community participation process is a part of 
democratic system also comprises community's decision making. Timothy (1999) in his study has illustrated that tourism planning which has public involvement fundamentals occurs from approaches to safeguard locals from the effect of tourism planning and get the benefits of tourism development. Public participation is not solitary about the link between the local government and the local community but it is an authorization process given to the local people for decision making (Kayat, 2002). The community participation is thought as a discussion or consultancy between the local residents and the local government based on the Skeffington Report (Britain, 1969). The economic contribution of community based tourism contains the improvement of local employment and natural resources; local knowledge, skills and ability for protection of local heritages and natural environment promotion and sustain the local attraction (Gautam, 2017). Community tourism has been prioritized in the national tourism agenda of many developed countries.

And some developing nations' community tourism policy includes terms, such as rural pro-poor tourism. Community participation in the tourism sector has been growing rapidly in the developed and some developing states, but community participation in tourism development have not been practically recognized as important yet in Kazakhstan. In this study the survey showed that albeit they realized developing tourism around the heritage site will lead to more benefits than other industries, both two settlements' residents had a weak awareness of how to be constructively involved in tourism. In many insular and less-developed regions, tourism has been developed and controlled by large, multinational tour companies who have little regards for local sociocultural and economic conditions (Timothy \& Ioannides, 2002). The pattern of power and wealth allocation among different groups in most developing countries is itself a reflection of their economic, social and political history and may vary from country to country (Todaro, 1994). Despite this, developing countries are dominated by a small group of well-organized and powerful elites, to a greater extent than developed nations are. Tosun (2000) claims the implementation of participatory tourism development methods requires radical changes in the socio-political, legal, administrative and economic structures of many developing countries and it is difficult for making decisions in the societies based on cumbersome social, economic and environmental trade.

\section{CONCLUSION}

Community participation requires considerable time, money and skills to organize and sustain participation (Paul, 1987). We admit that like most developing countries above scholars mentioned influential factors for citizens' participation in heritage and rural tourism also occur in our research area to some extent. Nevertheless, it may be said that it is impossible to discuss every relevant issue regarding local residents' participatory in tourism development at this heritage site in this article. Therefore, according to the findings of our investigation, we will discuss the most crucial three types of barriers that cause passive participation in the tourism activities at the Aksu-Jabagly natural world heritage tourism destination. In a word, active and higher community involvement in tourism will be realized when the following issues are fully taken into consideration:

(a) Fewer tourists' visitation to the tourist this destination: It can be clearly seen from the survey results in table 2 that all respondents from two settlements next to heritage tourism destination admitted the first most crucial limitation was tourists' visitation to the tourist this destination. In many developed and some developing countries, fewer tourists are not considered the primary reason of local community nonparticipation in tourism, since their inbound tourism is well developed. And Kazakhstan has a small population, larger territory and the inbound tourism just begins to develop, for this 
reason, the small number of tourists traveling to Aksu-Jabagly tourism destination is the first major barrier for local residents' participation in tourism.

(b) Lack of preferential policies for local residents' participation in tourism: In the Kazakhstan context, after independence transiting its economy from planned form to market form, the district (municipal)-level government is playing a leading role in the rural tourism development processes although (Li, 2004) argued that rural tourism development usually relies on the joint involvement of governments, tourism enterprises, tourists, and local residents. In Kazakhstan, government plays an active role as planners, investors, investment stimulators, promoters, educators and regulators even though privatization policy in economic development has been implemented after independence. However, diversification of industry has just become one of the vital tasks of Kazakhstan government recently. And the development of tourism industry in the remote rural areas has not been paid completely attention by the state. Therefore, the preferential policies for local communities' engagement in tourism industry are not implemented practically in the rural residential a reas (Akbar et al., 2020). As can be seen from the study results in Table 2, the weakness of the government's support for local residents' participation in the tourism industry by effective policies is seen as the second major cause of non-participation in tourism.

(c) Lack of necessary funds, labor force and knowledge of tourism planning: The introduction of tourism within communities usually requires funds to be allocated to develop a tourist infrastructure of facilities (Reed, 1997). These facilities often are based on Western standards even in the poorest host countries (Cohen, 1972). Lack of qualified human resources in the tourism sector in many local destinations in the developing world has stimulated an influx of employees from other parts of country to work in tourism (Tosun, 2000). And (Murphy, 1985) noted, effective management of tourism industry requires day-to-day and season-to-season operational decisions. If the local residents do not catch up with the modernized knowledge of tourism management, the low status, unskilled jobs associated with low wages and hard working conditions will always leave for them. These shortcomings have appeared as a major limitation to the local residents' participation in tourism development in many developing countries. Our findings from table 2 showed that aforementioned drawbacks were one of the primary obstacles for the Jabagly and Abaiyl settlement's people to engage in tourism industry. And the result of interviews with the experts showed that the local administration had not formulated any special training program for community residents and had failed to orientate them towards positive participation although they admitted one of the main influential factors for residents' participation in tourism had been lack of skills of planning, organizing and managing tourism activities. Therefore, because of aforementioned impediments, local community involvement in tourism development has still been resting on a passive participation stage.

Among above discussed three types of barriers which hinder community participation, fewer tourists' visitation and lack of preferential policies for local residents' participation in tourism were the crucial barriers highlighted by both selected community residents. In this regard, it is suggested that active measures must be taken to attract large number of tourists to this tourism destination, at the same time, government institutions should provide many favorable policies for local residents' participation in tourism. This study was not without its limitations that can affect the applicability of the results. This study applied perception of local residents in two different geographical locations to assess participation status of them in heritage tourism development. By having focused solely on local residents as well as interviewing three relevant experts, this 
study did not investigate the perceptions of other stakeholder groups, such as tourists, government/local authorities or tourism industry/the private sector. And this can be a limitation of the present research, however, it will give a chance for future study. Furthermore, in this study the sample size of respondents was not large and respondents were selected from only two communities adjacent to world heritage site, which are considered as the most affected. This might be thought as another limitation of the current study and this one should be handled in future studies.

\section{Aknowlegments}

This research was sponsored by the projects of the National Key Research and Development Project of China with grant no. (2016YFC0503307), the National Natural Science Foundation of China under Grant no. (41971192) and the Chinese Government Scholarship under Grant number (80001). Jumanov Smatulla Zhorauly, the deputy director of scientific research department of Aksu-Jabagly State Nature Reserve office in Jabagly village, provided great help during the field and social surveys.

Special thanks Beknur Izenbaev (PhD from M. Auezov South Kazakhstan State University in Shymkent) and Gauhar Ospan (L.N. Gumilyov Eurasian National University in Nur-Sultan), who helped to design questionnaires for local residents.

\section{REFERENCES}

Agrawal, A. (2000). Adaptive management in transboundary protected areas: The Bialowieza National Park and Biosphere Reserve as a case study. Environmental Conservation, 27, 326-333.

Akbar, I., Yang, Z., Han, F. \& Kanat, G. 2020. The Influence of Negative Political Environment on Sustainable Tourism: A Study of Aksu-Jabagly World Heritage Site, Kazakhstan. Sustainability, 12, 143.

Archabald, K. \& Naughton-Treves, L. (2001) Tourism revenue-sharing around national parks in Western Uganda: early efforts to identify and reward local communities. Environmental conservation, 28, 135-149.

Binns, T. \& Nel, E. (2002). Tourism as a local development strategy in South Africa. Geographical Journal, 168, 235-247.

Britain, G. (1969). Ministry of Housing and Local Government Committee on Public Participati on in Planning, People and Planning; Skeffington Report. HMSO.

Brohman, J. (1996). New directions in tourism for third world development. Annals of tourism research, 23, 48-70.

Butler, R., C. M. Hall \& Jenkins J. M. (1998). Tourism and recreation in rural areas.

Cohen, E. (1972). Toward a sociology of international tourism. Social research, 164-182.

Easterling, D. S. (2005). The residents' perspective in tourism research: A review and synthesis. Journal of Travel \& Tourism Marketing, 17, 45-62.

Flaherty, J. C., W. Gorman, J. T. Garibotto, J. R. Bussiere, M. D. Abelson \& Chastain D. P. (2006). Components and methods for patient infusion device. Google Patents.

Friedman, H.S., Prados, M.D., Wen, P. Y., Mikkelsen, T., Schiff, D., Abrey, L.E., Yung, W., Paleologos, N., Nicholas M.K. \& Jensen R. (2009). Bevacizumab alone and in combination with irinotecan in recurrent glioblastoma. J clin oncol, 27, 4733-4740.

Gautam, K. K. (2017). Tourism and Its Sustainability in a Local Community Participation Model: A Theoretical Discussion. 大阪産業大学経営論集= Osaka Sangyo University Journal of Business Administration, 19, 33-53.

Gu, H. \& Ryan, C. (2009). Hongcun and Xidi: Rural townships' experiences of tourism. In Tourism in China: Destinations, cultures and communities, 259-267. Routledge New York.

Gursoy, D., urowskiC. J \& Uysal, M. (2002). Resident attitudes: A structural modeling approach. Annals of tourism research, 29, 79-105.

Inskeep, E. (1991). Tourism planning: an integrated and sustainable development approach. Van Nostrand Reinhold.

Kayat, K. (2002). Power, social exchanges and tourism in Langkawi: Rethinking resident perceptions. International journal of tourism research, 4, 171-191.

Li, W. (2006). Community decisionmaking participation in development. Annals of tourism research, 33, $132-143$. 
Li, Y. (2004). Exploring community tourism in China: The case of Nanshan cultural tourism zone. Journal of sustainable tourism, 12, 175-193.

Li, Y. \& C. Hunter (2015). Community involvement for sustainable heritage tourism: a conceptual model. Journal of Cultural Heritage Management and Sustainable Development, 5, 248-262.

Mann, M. (2000). The community tourism guide: Exciting holidays for responsible travelers. London (Earthscan).

McCool, S.F. \& Martin, S.R. (1994). Community attachment and attitudes toward tourism development. Journal of Travel research, 32, 29-34.

Murphy, P. E. (1985). Tourism: A community approach. New York: Methuen. National Parks Today (199l): Green Guide for Tourism, 224-238.

Mynzhasarhyzy, D. (2018). Tourism is developing in Tulkibas district. Turkistan International.

Nicholas, L. N., B. Thapa \& Y. J. Ko (2009). Residents' perspectives of a world heritage site: The Pitons Management Area, St. Lucia. Annals of tourism research, 36, 390-412.

Paul, S. (1987). Community participation in development projects. World Bank Washington, DC.

Prentice, R. (1993). Community-driven tourism planning and residents' preferences. Tourism Management, 14, 218-227.

Rasoolimanesh, S. M. \& Jaafar, M. (2016). Community participation toward tourism development and conservation program in rural world heritage sites. Tourism-From Empirical Research Towards Practical Application. InTech.

Reed, M. G. (1997). Power relations and community-based tourism planning. Annals of tourism research, 24, 566-591.

Ryan, C. \& Montgomery D. (1994). The attitudes of Bakewell residents to tourism and issues in community responsive tourism. Tourism management, 15, 358-369.

Scheyvens, R. (2003). Local Involvement in Managing 12 Tourism. Tourism in destination communities, 229.

Sharpley, R. (2014). Host perceptions of tourism: A review of the research. Tourism Management, 42, 37-49.

Simmons, D. G. (1994). Community participation in tourism planning. Tourism management, 15, 98-108.

Sirisrisak, T. (2009). Conservation of Bangkok old town. Habitat International, 33, 405-411.

Stræde, S. \& Helles, F. (2000). Park-people conflict resolution in Royal Chitwan National Park, Nepal: buying time at high cost? Environmental Conservation, 27, 368-381.

$\mathrm{Su}$, M. M. \& Wall G. (2014). Community participation in tourism at a world heritage site: Mutianyu Great Wall, Beijing, China. International Journal of Tourism Research, 16, 146-156.

Svels, K. (2015). World heritage, tourism and community involvement: A comparative study of the High Coast (Sweden) and Kvarken Archipelago (Finland). Scandinavian Journal of Hospitality and Tourism, 15, 183-201.

Timothy, D. \& Ioannides D. (2002). Tour-operator hegemony: dependency, oligopoly, and sustainability in insular destinations. Island tourism and sustainable development: Caribbean, Pacific and Mediterranean experiences, 181-198.

Timothy, D. J. (1999). Participatory planningA view of tourism in Indonesia. Annals of tourism research, 26, 371-391.

Timothy, D. J. \& C. Tosun (2003). Appropriate planning for tourism in destination communities: Participation, incremental growth and collaboration. Tourism in destination communities, 181-204.

Todaro, M. P. (1994). Economics for a development world. New York: Longman.

Tosun, C. (1999). Towards a typology of community participation in the tourism development process. Anatolia, $10,113-134$.

Yung, E.H. \& Chan E.H. (2013). Evaluation for the conservation of historic buildings: Differences between the laymen, professionals and policy makers. Facilities, 31, 542-564.

*** KazakhstanNationalCommittee. 2014. Kazakhstan National Committee for the UNESCO Programme "Man and Biosphere": Aksu-Zhabagly Biosphere Reserve.

*** Limits to community participation in the tourism development process in developing countries. (2000). Tourism management, 21, 613-633.

*** Host perceptions of impacts: A comparative tourism study. (2002). Annals of tourism research, 29, $231-253$.

*** Expected nature of community participation in tourism development. (2006). Tourism management, 27, 493-504.

*** UNESCO. (2017). Kazakhstan Places Priority on Partnership with UNESCO for Peace and Security. In Annals of tourism research. MEDIA SERVICES.

*** UNWTO. (2013). UNWTO annual report 2012. UNWTO Madrid.

*** whc.unesco.org. 2016. Proposal for inscription on the UNESCO world cultural and natural heritage list: Nomination Dossier of Western Tien-Shan.

Submitted:

14.10.2019
Revised:

12.01.2020
Accepted and published online 16.01.2020 